\title{
Influence of A23187 and dibutyryl cyclic AMP on progestagen production by rat granulosa cells in vitro
}

\author{
B. K. Tsang, D. F. Mattice, M. Li* and E. K. Asem \\ Reproductive Biology Unit, Department of Obstetrics and Gynecology and Department of \\ Physiology, University of Ottawa, and The Loeb Institute for Medical Research, \\ Ottawa Civic Hospital, Ottawa, Ontario, Canada K1Y $4 E 9$
}

\begin{abstract}
Summary. The gonadotrophic regulation of progesterone production by rat granulosa cells was examined in a chemically-defined medium containing FSH, dibutyryl cyclic AMP $\left((\mathrm{Bu})_{2} \mathrm{cAMP}\right)$ and the calcium ionophore, A23187. FSH and A23187 alone significantly enhanced the production of pregnenolone, progesterone and its metabolite,

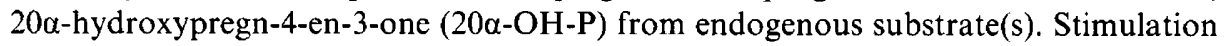
of progesterone production by $\mathrm{A} 23187$ was accompanied by an increase in $3 \beta$-hydroxy-

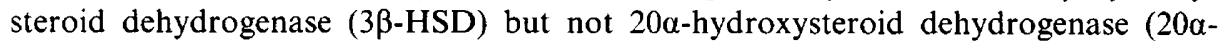
HSD) activity, as attested by enhancement of the metabolism of exogenous pregnenolone to progesterone but not of progesterone to $20 \mathrm{a}-\mathrm{OH}-\mathrm{P}$. In contrast, although $(\mathrm{Bu})_{2} \mathrm{cAMP}$ increased pregnenolone and progesterone production and the metabolism of exogenous progesterone to $20 \alpha-\mathrm{OH}-\mathrm{P}$, it failed to stimulate the conversion of exogenous pregnenolone to progesterone. The increase in progesterone production and in the conversion of exogenous pregnenolone to progesterone by FSH and A23187 was concentration- and time-dependent. Whereas maximal stimulation of de-novo progesterone synthesis by FSH was evident by $6 \mathrm{~h}$ (earliest time examined), a significant increase in the conversion of exogenous pregnenolone to progesterone in the presence of FSH or the ionophore was not noted until $12 \mathrm{~h}$ of incubation. Although a small but significant increase in progesterone production was also noted as early as $6 \mathrm{~h}$ of incubation in the presence of the calcium ionophore, this was markedly smaller than that elicited by FSH.

We conclude that the calcium ionophore A23187 and $(\mathrm{Bu})_{2}$ cAMP have similar as well as distinct effects on progesterone production in rat granulosa cells in vitro. We suggest that, while cAMP may be involved in the more rapid control by gonadotrophin of the production of the steroid via increased synthesis of pregnenolone and/or its metabolism to $20 \alpha-\mathrm{OH}-\mathrm{P}$, calcium may be important in the synthesis and metabolism of pregnenolone for the maintenance of steroidogenic capacity of the granulosa cells.
\end{abstract}

Keywords: calcium; cAMP; 3 $\beta$-hydroxysteroid dehydrogenase; 20a-hydroxysteroid dehydrogenase; steroidogenesis; granulosa cell; gonadotrophin action; rat

\section{Introduction}

Studies on the mechanism of hormone action have demonstrated that cAMP and calcium play important roles as transducers of hormonal stimuli in effecting cellular responses (Rasmussen \& Goodman, 1977; Borle, 1981). In the gonadotrophic regulation of ovarian steroidogenesis, both cAMP and calcium are involved in the control of progesterone synthesis (Marsh, 1976; Veldhuis \&

\footnotetext{
*Present address: Department of Animal Physiology, Fushan Veterinary College, Fushan, Guangdong, People's
} Republic of China. 
Klase, 1982a, b c; Carnegie \& Tsang, 1983, 1984; Tsang \& Carnegie, 1983, 1984; Veldhuis et al., 1984; Asem \& Hertelendy, 1986). While cAMP is believed to be important in the regulation of mitochondrial cholesterol uptake and of the activities of various steroidogenic enzymes, including cholesterol esterase and cholesterol side-chain cleavage enzymes (Behrman \& Armstrong, 1969; Marsh, 1976), the exact role of calcium in the gonadotrophic control of ovarian steroidogenesis remains to be determined.

In-vitro studies with rat granulosa cells have suggested that calcium is required for the gonadotrophic control of cellular cAMP levels (Tsang \& Carnegie, 1983; Eckstein et al., 1986). Incubation of granulosa cells with lanthanum, a calcium channel blocker, or an inhibitor of calmodulin, markedly reduced $\mathrm{LH}$ - and FSH-stimulated production of both cAMP and progesterone. Investigations with the calcium chelator, EGTA, have demonstrated that the calcium-dependence of progesterone production can be dissociated from the requirement for calcium in the synthesis of the cyclic nucleotide, suggesting that, in addition to regulating cAMP metabolism, calcium may be important at some step(s) on the steroidogenic pathway distal to the cAMP cascade (Carnegie \& Tsang, 1983; Tsang \& Carnegie, 1983).

In the present studies we have further examined the regulation of granulosa cell progesterone production by comparing the influence of the calcium ionophore, A23187, dibutyryl cAMP $\left[(\mathrm{Bu})_{2}\right.$ -cAMP] and FSH in vitro on different steps in the enzymic pathway of progestagen synthesis.

\section{Materials and Methods}

Immature Sprague-Dawley rats $(28 \pm 1$ days old $)$ were injected intraperitoneally with 4 i.u. pregnant mares' serum gonadotrophin (Equinex, Ayerst Labs., Inc., Montreal, Quebec, Canada) to induce follicular development. Follicles stimulated with this regimen were primarily at the antral stage when the animals were killed on the morning of Day $30 \pm \mathrm{I}$ (Fortune \& Armstrong, 1977). Granulosa cells were released, by follicle puncture, into Eagle's Minimal Essential Medium (MEM) containing $\mathrm{NaHCO}_{3}(2 \cdot 2 \mathrm{~g} / \mathrm{l})$, nonessential amino acids $(0 \cdot 1 \mathrm{mM})$, penicillin-streptomycin $(50000 \mathrm{U} / 1$ and $50000 \mu \mathrm{g} / \mathrm{l}$, respectively), and fungizone $(625 \mu \mathrm{g} / \mathrm{l})$ (all from GIBCO Laboratories, Burlington, Ontario, Canada), and collected by centrifugation $(180 \mathrm{~g}, 10 \mathrm{~min})$. Removal of non-viable cells was achieved with a sequential trypsin-DNase treatment (Farookhi, 1982). Briefly, the granulosa cell suspension ( $10^{6} \mathrm{cells} / \mathrm{ml}$ ) was incubated at $37^{\circ} \mathrm{C}$ with trypsin $(50 \mu \mathrm{g} / \mathrm{ml}$; Sigma Chemical Company, St Louis, MO, USA) for 1 min, excess soy bean trypsin inhibitor $(0.15 \mathrm{mg} / \mathrm{ml}$; Sigma) was added and the suspension was then incubated with DNase I $(25 \mu \mathrm{g} / \mathrm{ml}$; Sigma) for $5 \mathrm{~min}$. This procedure enriched the granulosa cell preparations from an initial value of $25-30 \%$ viable cells to a final level of $90-95 \%$. Cells $\left(3.5 \times 10^{5} / \mathrm{ml}\right)$ were cultured for 6,12 or $24 \mathrm{~h}$, at $36^{\circ} \mathrm{C}$ in an atmosphere of $5 \% \mathrm{CO}_{2}$ and $95 \%$ air in MEM containing various agents [FSH $(0-200 \mathrm{ng}$ NIAMDD-oFSH-13/ml), A23187 $(0-4 \mu \mathrm{g} / \mathrm{ml}$; Sigma) or $\left.(\mathrm{Bu})_{2} \mathrm{cAMP}(0 \cdot 1 \mathrm{mM})\right]$. To examine the influence of these agents on various steroidogenic steps, metabolism of exogenous steroid precursors was investigated in the presence of aminoglutethimide phosphate (AGP, $0.75 \mathrm{~mm}$; CIBA-Geigy Corporation, Ardsley, NY, USA), an inhibitor of cholesterol side-chain cleavage (Kowal, 1969) or cyanoketone $(0.25 \mu \mathrm{M}$; Winthrop Laboratories, Aurora, Ontario, Canada), an inhibitor of $3 \beta$-hydroxysteroid dehydrogenase (Goldman et al., 1965).

Medium collected at the end of the culture period was extracted twice with diethyl ether and the extract analysed for pregnenolone, progesterone, $17 \alpha$-hydroxyprogesterone (17 $\alpha-\mathrm{OH}-\mathrm{P})$ and $20 \alpha$-hydroxypregn-4-en-3-one (20 $\alpha$-OHP) by specific radioimmunoassays (Orczyk et al., 1979; Inaba et al., 1979). The antisera for the progesterone and $20 \alpha-\mathrm{OH}-\mathrm{P}$ assays showed negligible cross-reactivity $(0 \cdot 1 \%)$ with other progestagens, androgens and oestrogens, with the exception of the latter which cross-reacted significantly with $20 \beta$-hydroxypregn-4-en-3-one ( $8 \cdot 7 \%)$. The antiserum for the pregnenolone assay exhibited significant cross-reactivity with $17 \alpha$-hydroxypregnenolone $(12 \cdot 7 \%)$, 5-pregnene$3 \beta, 20 \alpha$-diol $(25 \cdot 0 \%)$, 5-pregnene-3 $\beta, 20 \beta$-diol $(8 \cdot 3 \%)$, dehydroepiandrosterone $(8 \cdot 7 \%)$ and 5 -androstene- $3 \beta, 17 \beta$-diol $(5 \cdot 6 \%)$. Cyanoketone cross-reacted slightly but insignificantly with antisera for progesterone $(0 \cdot 001 \%)$ and $20 \alpha-\mathrm{OH}-\mathrm{P}$ $(0.02 \%)$ while AGP and A23187 had negligible cross-reactivities with antisera for pregnenolone, progesterone and $20 \alpha-\mathrm{OH}-\mathrm{P}(<0.001 \%)$. The $17 \alpha-\mathrm{OH}-\mathrm{P}$ antiserum cross-reacted with pregn-4-en-20 $\beta$-ol-3-one $(1 \cdot 2 \%)$ but $<0 \cdot 1 \%$

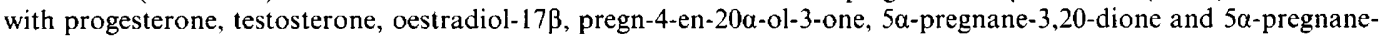
3 $\alpha$-ol-20-one.

Results were assessed statistically by analysis of variance. Significance of difference between groups was determined with Duncan's new multiple range test or Student's $t$ test.

\section{Results}

The influence of FSH and the calcium ionophore A23187 on progesterone, $17 \alpha-\mathrm{OH}-\mathrm{P}$ and $20 \alpha-$ $\mathrm{OH}-\mathrm{P}$ production by rat granulosa cells in vitro is summarized in Table 1 . Whereas both FSH 
(75 ng/ml) and A23187 ( $1 \mu \mathrm{g} / \mathrm{ml})$ significantly enhanced $(P<0.00 \mathrm{l})$ progesterone and $20 \alpha-\mathrm{OH}-\mathrm{P}$ production (Table 1; Fig. 1), synthesis of $17 \alpha-\mathrm{OH}-\mathrm{P}$ by granulosa cells was unaltered by either FSH or A23187 $(P>0.05$; Table 1$)$. There was a tendency for the ionophore to be slightly more effective than FSH in increasing 20a-OH-P production from endogenous substrates but this difference was not statistically significant ( $P>0.05$; Table 1 ). The effect of A23187 on progesterone production appeared to be due to its stimulatory action on pregnenolone synthesis and on the metabolism of the latter to progesterone (Fig. 1). A23187 $(0 \cdot 25-0.5 \mu \mathrm{g} / \mathrm{ml})$ significantly increased pregnenolone accumulation during a $24 \mathrm{~h}$ incubation period $(P<0.01)$ but $2 \mu \mathrm{g} / \mathrm{ml}$ was inhibitory $(P<0.05)$. Like FSH, which stimulated the conversion of exogenous pregnenolone to progesterone in the presence of AGP (to inhibit endogenous pregnenolone formation) (Fig. 2), the calcium ionophore A23187 also increased the accumulation of progesterone from exogenous pregnenolone in a concentration-dependent manner (Fig. 1).

Table 1. Influence of FSH and A23187 on progestagen production by rat granulosa cells during a 24 -h culture period

\begin{tabular}{|c|c|c|c|}
\hline \multirow[b]{2}{*}{ Groups } & \multicolumn{3}{|c|}{ Steroid produced $\left(\mathrm{pg} / 10^{5}\right.$ cells) } \\
\hline & Progesterone & $17 \alpha-\mathrm{OH}-\mathrm{P}$ & $20 \alpha-\mathrm{OH}-\mathrm{P}$ \\
\hline Control & $44.8 \pm 13$ & $34 \cdot 7 \pm 6 \cdot 7$ & $167 \pm 17$ \\
\hline $\mathrm{FSH}(75 \mathrm{ng} / \mathrm{ml})$ & $554 \pm 118^{*}$ & $32 \cdot 0 \pm 2 \cdot 7$ & $1297 \pm 189^{*}$ \\
\hline A23187 $(1 \mu \mathrm{g} / \mathrm{ml})$ & $223 \pm 45^{*}$ & $26 \cdot 2 \pm 1 \cdot 4$ & $1603 \pm 299^{*}$ \\
\hline
\end{tabular}

Values are mean \pm s.e.; $n=20 ; 5$ experiments.

${ }^{*} P<0.01$ vs control in the same column.

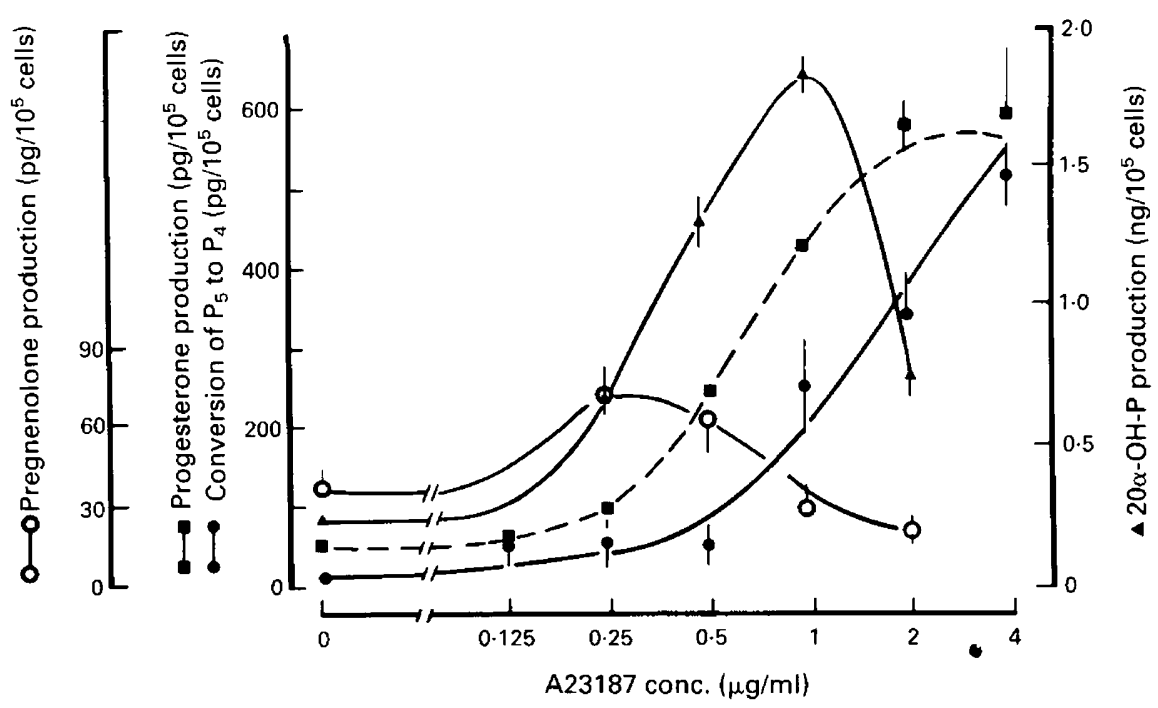

Fig. 1. Influence of A23187 on production of progesterone ( $\boldsymbol{\square}), 20 \alpha-\mathrm{OH}-\mathrm{P}(\boldsymbol{\Delta})$ and pregnenolone $(O)$ and on conversion of exogenous pregnenolone $\left(\mathrm{P}_{5} ; 0.1 \mu \mathrm{M}\right)$ to progesterone $\left(\mathrm{P}_{4}\right)$ (in the presence of $0.75 \mathrm{~mm}$-AGP) (O) by rat granulosa cells incubated for $24 \mathrm{~h}$ in the presence of various concentrations of the ionophore $(0-4 \mu \mathrm{g} / \mathrm{ml})$. Values are mean \pm s.e. $(n=12$; 3 experiments). 


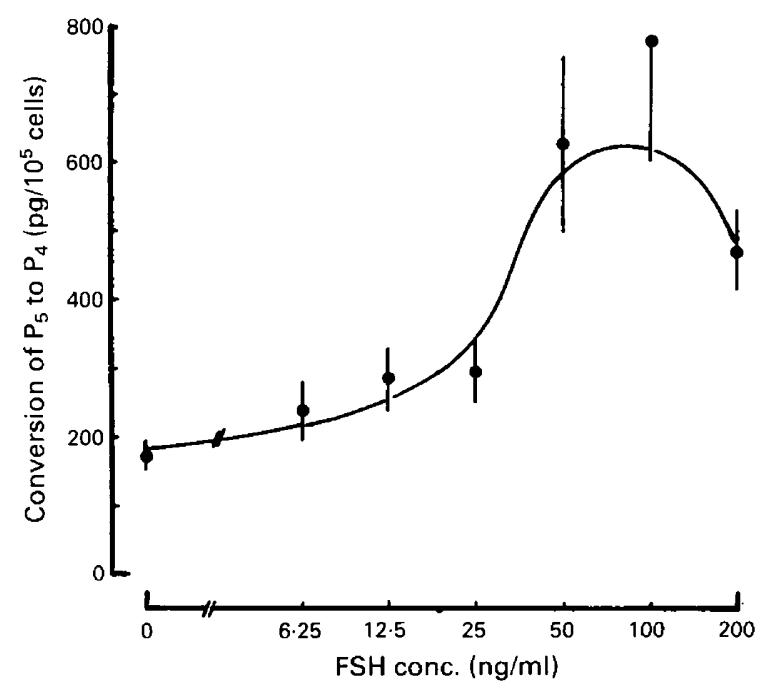

Fig. 2. Concentration-dependent stimulation by FSH of rat granulosa cell conversion of exogenous pregnenolone $\left(\mathrm{P}_{5} ; 0 \cdot 1 \mu \mathrm{M}\right)$ to progesterone $\left(\mathrm{P}_{4}\right)$ during a 24-h culture period. Medium contained AGP $(0.75 \mathrm{~mm})$ to inhibit production of endogenous pregnenolone. Values are the means \pm s.e. $(n=12 ; 3$ experiments $)$.

Figure 3 illustrates a time-course study of the regulation of granulosa cells progesterone production by FSH $(75 \mathrm{ng} / \mathrm{ml})$ and A23187 $(1 \mu \mathrm{g} / \mathrm{ml})$ in vitro. Addition of FSH to the incubation medium resulted in a stimulation (400\%) of de-novo progesterone production within $6 \mathrm{~h}$ (earliest time examined). A small but significant increase in progesterone production was also noted in granulosa cells incubated in the presence of the calcium ionophore for $6 \mathrm{~h}$. This latter response, however, was minimal when compared with that observed in the presence of FSH. In the presence of AGP $(0.75 \mathrm{mM})$, the conversion of exogenous pregnenolone to progesterone elicited by $\mathrm{FSH}$ or A23187 occurred only after $12 \mathrm{~h}$ (Fig. 3). At a concentration which markedly stimulated pregnenolone and progesterone production $(0.1 \mathrm{mM}),(\mathrm{Bu}){ }_{2} \mathrm{cAMP}$, an active analogue of cAMP, had no significant effect $(P>0.05)$ on the synthesis of progesterone from exogenous pregnenolone (Table 2). Moreover, while FSH $(75 \mathrm{ng} / \mathrm{ml}),(B u)_{2}$ cAMP $(0.1 \mathrm{~mm})$ and cholera toxin $(10 \mathrm{ng} / \mathrm{ml})$ significantly increased the metabolism of progesterone to $20 \alpha-\mathrm{OH}-\mathrm{P}$ by 250,300 and $500 \%$ respectively (Table 3), A23187, at a concentration $(1 \mu \mathrm{g} / \mathrm{ml})$ which stimulated progesterone production as well as the metabolism of pregnenolone to progesterone, was ineffective $(P>0.05)$.

Figure 4 illustrates the possible dependence on protein synthesis stimulation by FSH and A23187 in granulosa cell progesterone and $20 \alpha-\mathrm{OH}-\mathrm{P}$ production in vitro. Addition of cycloheximide, an inhibitor or protein synthesis, to the culture medium $(28 \mathrm{ng} / \mathrm{ml})$ markedly reduced the production of progesterone and $20 \alpha-\mathrm{OH}-\mathrm{P}$ elicited by FSH and A23187. Maximal inhibition of progesterone production occurred at an inhibitor concentration of $28 \mathrm{ng} / \mathrm{ml}$; a higher concentration further decreased (by $80-90 \%$ ) production of $20 \alpha-\mathrm{OH}-\mathrm{P}$ (Fig. 4).

\section{Discussion}

Results from our earlier studies have suggested that calcium plays an important regulatory role in rat granulosa cell progesterone synthesis at point(s) in the steroidogenic pathway distal to the cAMP cascade (Carnegie \& Tsang, 1984; Tsang \& Carnegie, 1984). Although the regulation of cholesterol availability by cholesterol esterase (Behrman \& Armstrong, 1969) and mitochondrial uptake (Marsh, 1976), cholesterol side-chain cleavage enzyme cytochrome P-450 levels (Toaff et 


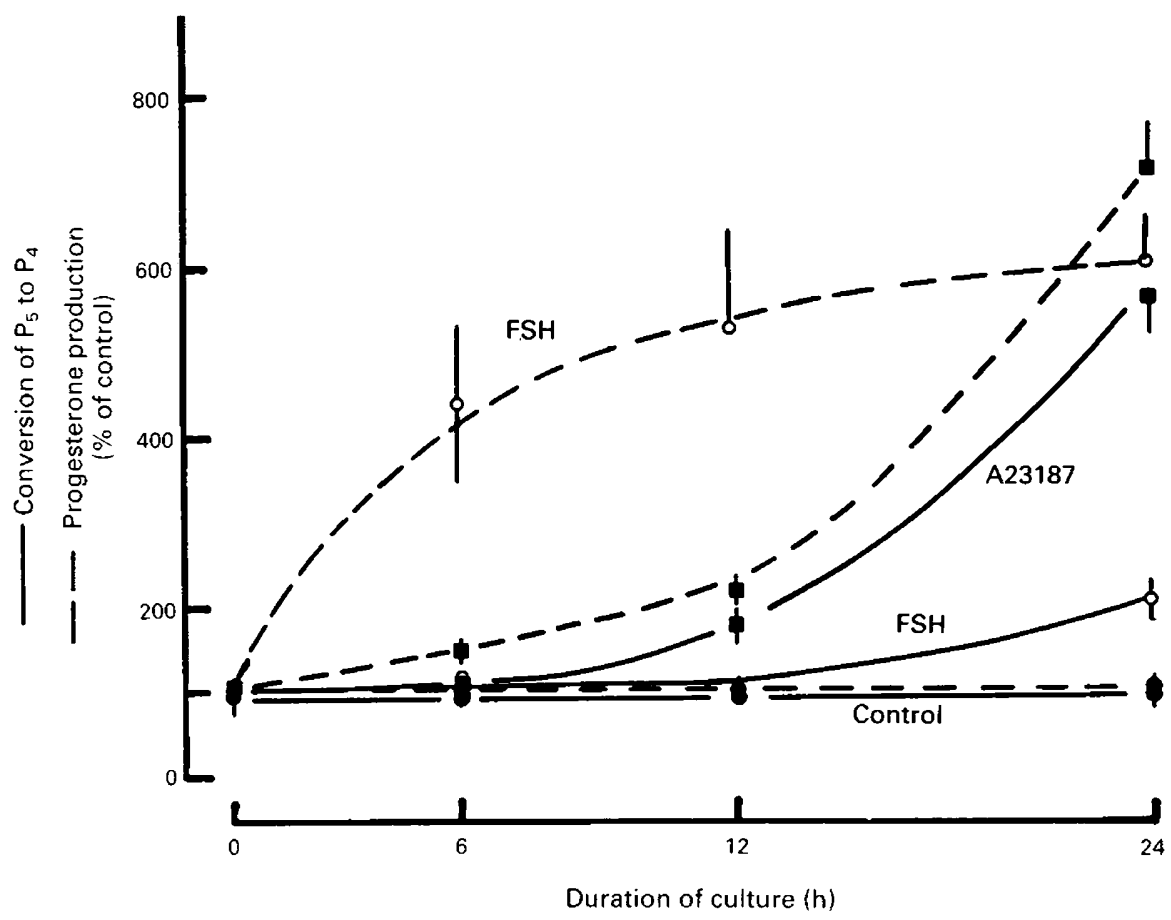

Fig. 3. Time course of progesterone production $(---)$ and conversion of exogenous pregnenolone $\left(\mathrm{P}_{5} ; 0.1 \mu \mathrm{M}\right)$ to progesterone $\left(\mathrm{P}_{4}\right)$ in the presence of AGP $(0.75 \mathrm{~mm})(-)$ by rat granulosa cells incubated in the absence of $(O)$ or presence of FSH $(75 \mathrm{ng} / \mathrm{ml} ; 0)$ or A23187 $(1 \mu \mathrm{g} / \mathrm{ml}$;

D). Progesterone production and conversion of pregnenolone to progesterone at $0,6,12$ and $24 \mathrm{~h}$ in the control groups were $1 \cdot 2,10 \cdot 1,21 \cdot 5,35 \cdot 9$ and $1 \cdot 9,20 \cdot 0,36 \cdot 3,50 \cdot 7 \mathrm{pg} / 10^{5}$ cells, respectively. Values are mean \pm s.e. $(n=16 ; 4$ experiments $)$.

Table 2. Influence of $(\mathrm{Bu})_{2} \mathrm{cAMP}$ on pregnenolone and progesterone production by rat granulosa cells cultured for $24 \mathrm{~h}$

\begin{tabular}{|c|c|c|c|}
\hline \multirow[b]{2}{*}{ Experiment } & \multirow[b]{2}{*}{ Treatment } & \multicolumn{2}{|c|}{ Steroid produced $\left(\mathrm{pg} / 10^{5}\right.$ cells $)$} \\
\hline & & Pregnenolone & Progesterone \\
\hline A & $\begin{array}{l}\text { None } \\
(\mathrm{Bu})_{2} \mathrm{cAMP}(0.1 \mathrm{mM})\end{array}$ & $\begin{array}{l}25 \cdot 7 \pm 4 \cdot 0 \\
83 \cdot 3 \pm 5 \cdot 3 *\end{array}$ & $\begin{array}{l}76 \cdot 4 \pm 8 \cdot 7 \\
594 \pm 37^{*}\end{array}$ \\
\hline B & $\begin{array}{l}\text { AGP }(0.75 \mathrm{~mm})+\text { pregnenolone }(0.1 \mu \mathrm{M}) \\
\text { AGP }(0.75 \mathrm{mM})+\text { pregnenolone }(0.1 \mu \mathrm{M}) \\
\quad+(\mathrm{Bu})_{2} \mathrm{CAMP}(0.1 \mathrm{mM})\end{array}$ & - & $\begin{array}{l}68 \cdot 8 \pm 16 \cdot 8 \\
88 \cdot 8 \pm 15 \cdot 9\end{array}$ \\
\hline
\end{tabular}

Values are mean \pm s.e.; $n=8 ; 2$ experiments.

${ }^{*} P<0.01$ vs no treatment in same column.

al., 1983) and 3ß-HSD activity (Jones \& Hsueh, 1982) are under the control of gonadotrophic hormones, the exact site(s) on the steroidogenic pathway which are calcium dependent remains to be defined. Results from the present investigation have demonstrated that A23187, like FSH, significantly stimulated granulosa cell production of pregnenolone, progesterone and $20 \alpha-\mathrm{OH}-\mathrm{P}$. Calcium is known to stimulate pregnenolone production in testicular (Janszen et al., 1976) and adrenal (Farese \& Prudente, 1978) mitochondrial preparations and to increase the rate of 
Table 3. Effect of A23187, FSH, $(\mathrm{Bu})_{2}$ cAMP and cholera toxin on the conversion of exogenous progesterone to $20 \alpha-\mathrm{OH}-\mathrm{P}$ by rat granulosa cells during a $24-\mathrm{h}$ period

\begin{tabular}{|c|c|c|}
\hline Experiment & Treatment & $\begin{array}{l}\text { 20a-OH-P produced } \\
\left(\mathrm{pg} / 10^{5} \text { cells }\right)\end{array}$ \\
\hline A & $\begin{array}{l}\text { Cyanoketone }(\text { CKT } 25 \mu \mathrm{M}) \\
\text { CKT + progesterone }(0 \cdot 1 \mu \mathrm{M}) \\
\text { CKT + progesterone + } \\
\text { A23187 }(1 \mu \mathrm{g} / \mathrm{ml}) \\
\text { CKT + progesterone + } \\
\text { FSH }(75 \mathrm{ng} / \mathrm{ml})\end{array}$ & $\begin{array}{l}431 \pm 35 \\
753 \pm 26 \\
753 \pm 23 \\
1928 \pm 86^{*}\end{array}$ \\
\hline B & $\begin{array}{l}\text { CKT + progesterone } \\
\text { CKT + progesterone+ } \\
(\mathrm{Bu})_{2} \text { cAMP }(0.1 \mu \mathrm{M}) \\
\text { CKT + progesterone }+ \\
\text { cholera toxin }(10 \mathrm{ng} / \mathrm{ml})\end{array}$ & $\begin{array}{c}275 \pm 38 \\
752 \pm 76^{*} \\
1296 \pm 178^{*}\end{array}$ \\
\hline
\end{tabular}

Values are mean \pm s.e.; $n=8 ; 2$ experiments.

${ }^{*} P<0.01$ vs $\mathrm{CKT}+$ progesterone in same experiment.

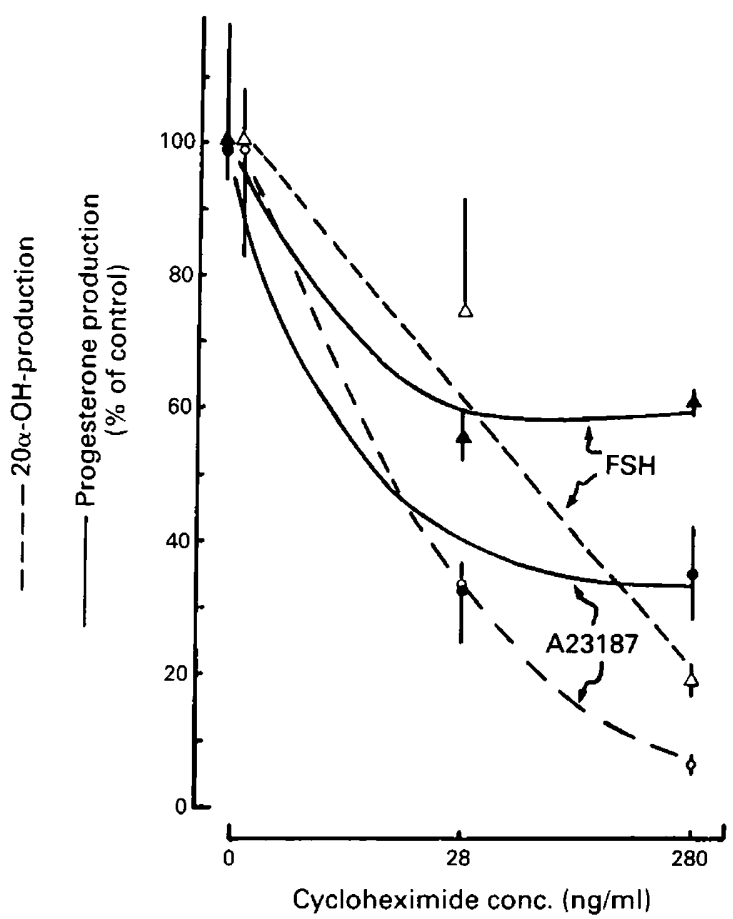

Fig. 4. Effects of cycloheximide on FSH- $(75 \mathrm{ng} / \mathrm{ml} ; \Delta, \Delta)$ and $\mathrm{A} 23187(1 \mu \mathrm{g} / \mathrm{ml} ; \bigcirc, 0)$ stimulated progesterone $(-)$ and $20 \alpha-\mathrm{OH}-\mathrm{P}(--)$ production by granulosa cells during $24 \mathrm{~h}$. In the absence of cycloheximide, production of progesterone and $20 \alpha-\mathrm{OH}-\mathrm{P}$ was $50 \cdot 3$ and $193 \mathrm{pg} / 10^{5}$ cells (control), 625 and $1467 \mathrm{pg} / 10^{5}$ cells (A23187 group). Values are mean \pm s.e. ( $n=8 ; 2$ experiments). 
side-chain cleavage of labelled cholesterol in testicular tissue (Drosdowsky et al., 1965). Moreover, incubation of adrenal and testicular cells with calcium and calmodulin entrapped in liposomes resulted in a significant increase in mitochondrial cholesterol accumulation (Hall et al., 1981a, b). Whether calcium is important in controlling any of the above steroidogenic processes in the granulosa cell awaits further investigations.

A significant finding of the present studies involves the steroidogenic step catalysed by the $3 \beta$-HSD. Our results with respect to the stimulatory effects of FSH and A23187 on conversion of exogenous pregnenolone to progesterone were rather unexpected, since this step is known not to be regulated by gonadotrophins (Asem et al., 1984; Shemesh et al., 1984) and to be independent of the influence of calcium in pig (Velduis \& Klase, 1982a) and chicken (Asem \& Hertelendy, 1986) granulosa cells. However, these observations stemmed from studies done in short-term incubation ( $34 \mathrm{~h}$ ) whereas ours were made after $24 \mathrm{~h}$ of culture. Nevertheless, our observations are in keeping with the reported stimulatory action of gonadotrophins on $3 \beta-H S D$ in rat granulosa cells in longterm culture (Dorrington \& Armstrong, 1979; Zeleznik, 1979; Jones \& Hsueh, 1982; Jones et al., 1983). Moreover, the report of Shemesh et al. (1984) that A23187 and 3-isobutyl-1-methylxanthine, both known to raise intracellular free calcium levels albeit by different mechanisms, stimulated exogenous pregnenolone conversion to progesterone in bovine placentomes gives support to our findings. Our findings extend these observations and provide evidence consistent with an involvement of calcium in the regulation of this enzyme in the granulosa cell.

Although calcium is implicated in the action of A23187 on the 3 $\beta$-HSD catalysed step, other possible effects of the ionophore cannot be ruled out. A23187 may facilitate inositol-1,4,5triphosphate and diacylglycerol production, with enhanced progesterone production resulting from increases in intracellular calcium and protein kinase C activation, respectively (Dimino et al., 1987; Wang \& Leung, 1987). Veldhuis \& Klase (1982b) showed that higher concentration of A23187 $(10 \mu \mathrm{g} / \mathrm{ml})$ significantly inhibited LH-stimulated progesterone production, depleted cell calcium stores and inhibited protein synthesis in pig granulosa cells. Although A23187 may have non-specific effects on granulosa cell function, such deleterious actions are observed mainly at excessively high concentrations $(\geq 2 \mu \mathrm{g} / \mathrm{ml})$. Our findings that chelation of extracellular $\mathrm{Ca}^{2+}$ with EGTA ( $\geq 2.7 \mathrm{mM}$ ) suppresses the A23187 $(1 \mu \mathrm{g} / \mathrm{ml}$ )-induced progesterone production (data not shown) lends support to the notion that the effect of the ionophore noted in the present studies may be calcium dependent.

The increase in net progesterone production by low concentration of $\mathrm{A} 23187(<1 \mu \mathrm{g} / \mathrm{ml}) \mathrm{did}$ not appear to be a result of decreased conversion of progesterone to $20 \alpha-\mathrm{OH}-\mathrm{P}$, as production of the latter steroid from exogenous progesterone was not affected by the ionophore. This conclusion was also supported by our observation that FSH, $(\mathrm{Bu})_{2} \mathrm{cAMP}$ and cholera toxin but not A23187 significantly increased metabolism of exogenous progesterone to $20 \alpha-\mathrm{OH}-\mathrm{P}$. Our observation that

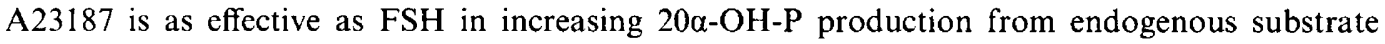
suggests that the $20 \alpha$-HSD step is not rate-limiting and that the increased secretion of the steroid reflects increased substrate (progesterone) availability resulting from FSH or A23187 stimulation. It should, however, be noted that whereas A23187 significantly increased granulosa cell progesterone production from endogenous and exogenous substrate in a concentration-dependent manner $(1-4 \mu \mathrm{g} / \mathrm{ml}), 20 \alpha-\mathrm{OH}-\mathrm{P}$ production from endogenous sterol was significantly enhanced with increasing concentration of the ionophore only up to $1 \mu \mathrm{g} / \mathrm{ml}$. These findings suggest a possible non-specific inhibitory action of A23187 on 20 $\alpha$-HSD activity at high concentration and necessitate caution in the interpretation of the findings obtained under the latter conditions. Our findings are in good agreement with the earlier observation that ovarian $20 \alpha-\mathrm{HSD}$ is under the control of gonadotrophin (Eckstein \& Nimrod, 1979; Jones \& Hsueh, 1981) and further suggests that this regulation may involve a cAMP-mediated mechanism.

Previous studies with testicular and adrenal tissues have demonstrated a requirement for calcium in the synthesis of proteins necessary for steroid hormone production (Hall \& Eik-Nes, 1962; Farese, 1971a,b). Whereas dependence on protein synthesis in LH-stimulated steroid 
production has been demonstrated in the ovary (Hermier et al., 1971; Arthur \& Boyd, 1974; Toaff et al., 1979; Strauss et al., 1981), a role for calcium in this process has not been established. Results from the present investigations have shown that cycloheximide markedly inhibited granulosa cell progesterone and $20 \alpha-\mathrm{OH}-\mathrm{P}$ production elicited by FSH in vitro. While $\mathrm{FSH}$ is known to stimulate progesterone biosynthesis via cAMP, it is possible that a significant effect of the gonadotrophin may be mediated by a calcium-dependent system involving the synthesis of new protein. This idea is also consistent with the observed lag time in the stimulation of progesterone production by A23187 and on the conversion of exogenous pregnenolone to progesterone by FSH or the ionophore. Caution should, however, be exercised in the interpretation of the findings as they are only suggestive of a requirement for protein synthesis and the inhibitor may have non-specific actions. Moreover, whether the protein(s) presumably synthesized is involved in the intracellular transport of steroid precursors and intermediates, components of the cholesterol side-chain cleavage enzyme or of the $3 \beta$-HSD systems or modulators thereof remains to be determined.

Our findings do not negate the fact that the mitochondrial cholesterol side-chain cleavage enzyme catalyses the rate-limiting step along the steroidogenic pathway, neither do they promote $3 \beta-\mathrm{HSD}$ as a rate-limiting enzyme. Rather this communication adds to the growing evidence that the $3 \beta$-HSD may be an important controlling step in hormone-induced steroidogenesis, depending on experimental conditions as well as type and/or source of steroidogenic tissue.

We thank the National Institute of Arthritis, Metabolism and Digestive Diseases for the purified preparation of FSH; Dr G. D. Niswender (Colorado State University, Fort Collins, Colorado) for the pregnenolone antiserum; Dr D. T. Armstrong (University of Western Ontario,

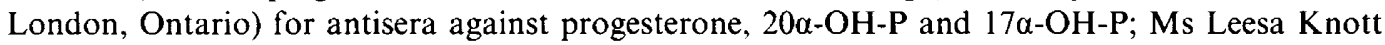
for technical assistance; and Ms Edith Chan for help with the preparation of the manuscript. The research was supported by grants from the Medical Research Council of Canada (MT-7793) and the Kiwanis Club of Ottawa Medical Foundation and was completed in partial fulfilment by D.F.M. of the requirements for the M.Sc. degree at the University of Ottawa.

\section{References}

Arthur, J.R. \& Boyd, G.S. (1974) The effect of inhibitors of protein synthesis on cholesterol side chain cleavage in the mitochondria of luteinized rat ovaries. Eur. J. Biochem. 49, 117-127.

Asem, E.K. \& Hertelendy, F. (1986) Role of calcium in luteinizing hormone-induced progesterone and cyclic AMP production in granulosa cells of the hen ( Gallus domesticus). Gen. comp. Endocrinol. 62, 120-128.

Asem, E.K., Zakar, T., Biellier, H.V. \& Hertelendy, F. (1984) Progesterone production in granulosa cells of the domestic fowl: effects of incubation media, $\mathrm{pH}$, cell density and some other factors. Domestic Anim. Endocrinol. 1, 235-249.

Behrman, H.R. \& Armstrong, D.T. (1969) Cholesterol esterase stimulation by luteinizing hormone in luteinized rat ovaries. Endocrinology 35, 474 480 .

Borle, A.B. (1981) Control, modulation, and regulation of cell calcium. Rev. Physiol. Biochem. Pharmacol.90, 13-153.

Carnegie, J.A. \& Tsang, B.K. (1983) Follicle stimulating hormone-regulated granulosa cell steroidogenesis: involvement of the calcium-calmodulin system. $\mathrm{Am}$. J. Obstet. Gynecol. 145, 223-228.

Carnegie, J.A. \& Tsang, B.K. (1984) The calciumcalmodulin system participation in the regulation of steroidogenesis at different stages of granulosa cell differentiation. Biol. Reprod. 30, 515-522.

Dimino, M.J., Sadighian, J.J. \& Waddell, B.J. (1987) Effects of inositol triphosphate and diacylglycerol on granulosa of porcine ovarian follicles. Biol. Reprod. 36 (Suppl. 1), 154, Abstr.

Dorrington, J.H. \& Armstrong, D.T. (1979) Effects of FSH on gonadal functions. Recent Prog. Horm. Res. 35, 301-333.

Drosdowsky, M., Menon, K.N.J., Forchielli, E. \& Dorfman, R. (1965) Requirements of the cholesterol side-chain cleavage enzyme system of rat-testis mitochondria. Biochim. Biophys. Acta 104, 229-236.

Eckstein, B. \& Nimrod, A. (1979) Effect of human chorionic gonadotropin and prolactin on $20 \alpha-$ hydroxysteroid dehydrogenase activity in granulosa cells of immature rat ovary. Endocrinology 104, $711-714$.

Eckstein, N., Eshel, A., Eli, Y., Ayalon, D. \& Naor, Z. (1986) Calcium-dependent actions of gonadotropinreleasing hormone agonist and luteinizing hormone upon cyclic AMP and progesterone production in rat ovarian granulosa cells. Molec. cell. Endocr. 47, 91-98.

Farese, R.V. (1971a) Calcium as mediator of ACTH 
action on adrenal protein synthesis. Science, N.Y. 173, $447-450$.

Farese, R.V. (197ib) Stimulatory effect of $\mathrm{Ca}^{2+}$ on protein synthesis in adrenal cell-free systems as related to trophic hormone action. Endocrinology 89, 1064-I074.

Farese, R.V. \& Prudente, W.J. (1978) On the role of calcium in adrenocorticotropin-induced changes in mitochondrial pregnenolone synthesis. Endocrinology 103, 12641274.

Farookhi, R. (1982) Granulosa cell fusion allows heterologous receptor stimulation of adenylate cyclase and progesterone accumulation. Endocrinology 110, $1061-1063$.

Fortune, J.E. \& Armstrong, D.T. (1977) Androgen production by theca and granulosa isolated from proestrous rat follicles. Endocrinology 100, 13411347.

Goldman, A.S., Yakovac, W.C. \& Bongiovanni, A.M. (1965) Persistent effects of a synthetic androstene derivative on activities of $3 \beta$-hydroxysteroid dehydrogenase and glucose-6-phosphate dehydrogenase in rats. Endocrinology 77, 1105-1118.

Hall, P.F. \& Eik-Nes, K.B. (1962) The action of gonadotropic hormone on rabbit testis in vitro. Biochim. Biophys. Acta 63, 41 l-422.

Hall, P.F., Osawa, S. \& Mrotek, J. (1981a) The influence of calmodulin on steroid synthesis in Leydig cells from rat testis. Endocrinology 109, 1677-1682.

Hall, P.F., Osawa, S. \& Thomasson, C.L. (1981b) A role for calmodulin in the regulation of steroidogenesis. $J$. Cell Biol. 90, $402-407$.

Hermier, C., Combarnous, Y. \& Jutisz, M. (1971) Role of a regulating protein and molecular oxygen in the mechanism of action of luteinizing hormone. Biochim. Biophys. Acta 244, 625-633.

Inaba, T., Wiest, W.G. \& Niswender, G.D. (1979) Radioimmunoassay of serum and ovarian pregnenolone in immature rats. Steroids 34, 663675.

Janszen, F.H.A., Cooke, B.A., van Driel, M.J.A. \& van der Molen, H.J. (1976) Purification and characterization of Leydig cells from rat testes. J. Endocr. 770, 345-359.

Jones, P.B.C. \& Hsueh, A.J.W. (1981) Direct stimulation of ovarian progesterone metabolizing enzyme by gonadotropin-releasing hormone in cultured granulosa cells. J. biol. Chem. 256, 1248-1254.

Jones, P.B.C. \& Hsueh, A.J.W. (1982) Regulation of ovarian $3 \beta$-hydroxysteroid dehydrogenase activity by gonadotropin-releasing hormone and folliclestimulating hormone in cultured rat granulosa cells. Endocrinology 110, 1663-1671.

Jones, P.B.C., Valk, C.A. \& Hsueh, A.J.W. (1983) Regulation of progestin biosynthetic enzymes in cultured rat granulosa cells: effects of prolactin, $\mathbf{B}_{2}-$ adrenergic agonists, human chorionic gonadotropin and gonadotropin releasing hormone. Biol. Reprod. 29, 572-585.

Kowal, J. (1969) Adrenal cells in tissue culture IV. Use of an inhibitor of steroid synthesis for the study of ACTH action. Endocrinology 85, 270-279.
Marsh, J.M. (1976) The role of cyclic AMP in gonadal steroidogenesis. Biol. Reprod. 14, $30-53$.

Orczyk, G.P., Hichens, M., Arth, G. \& Behrman, H.R. (1979) Progesterone and 20a-dihydroprogesterone. In Methods of Hormone Radioimmunoassay, pp. 701-713. Eds B. M. Jaffe \& H. R. Behrman. Academic Press, New York.

Rasmussen, H. \& Goodman, D.B.P. (1977) Relationship between calcium and cyclic nucleotides in cell activation. Physiol. Rev. 57, 421-509.

Shemesh, M., Hansel, W. \& Strauss, J.F., III (1984) Calcium-dependent cyclic nucleotide-independent steroidogenesis in the bovine placenta. Proc. natn. Acad. Sci. USA 81, 6403-6409.

Strauss, J.F., III, Schuler, L.A., Rosenblum, M.R. \& Tanaka, T. (1981) Cholesterol metabolism by ovarian tissue. Adv. Lipid Res. 18, 99-157.

Toaff, M.E., Strauss, J.F., III, Flickinger, G.L. \& Shattil, S.J. (1979) Relationship of cholesterol supply to luteal mitochondrial steroid synthesis. J. biol. Chem. 254, 3977-3982.

Toaff, M.E., Strauss, J.F., III \& Hammond, J.M. (1983) Regulation of cytochrome $\mathrm{P}-450_{\text {sce }}$ in immature porcine granulosa cells by FSH and estradiol. Endocrinology 112, 1156-1158.

Tsang, B.K. \& Carnegie, J.A. (1983) Calcium requirement in the gonadotropic regulation of rat granulosa cell progesterone production. Endocrinology 113, $763-769$.

Tsang, B.K. \& Carnegie, J.A. (1984) Calcium-dependent regulation of progesterone production by isolated rat granulosa cells: effects of the calcium ionophore A23187, prostaglandin $E_{2}$, dl-isoproterenol and cholera toxin. Biol. Reprod. 30, 787-794.

Veldhuis, J.D. \& Klase, P.A. (1982a) Mechanisms by which calcium ions regulate the steroidogenic actions of luteinizing hormone in isolated ovarian cells in vitro. Endocrinology' 111, 1-6.

Veldhuis, J.D. \& Klase, P.A. (1982b) Role of calcium ions in the stimulatory actions of luteinizing hormone in isolated ovarian cells: studies with divalent-cation ionophores. Biochem. Biophys. Res. Commun. 104, $603-610$.

Veldhuis, J.D. \& Klase, P.A. (1982c) Calcium ions modulate hormonally stimulated progesterone production in isolated ovarian cells. Biochem. $J .202,381-386$.

Veldhuis, J.D., Klase, P.A., Demers, L.M. \& Chafouleas, J.G. (1984) Mechanisms subserving calcium's modulation of luteinizing hormone action in isolated swine granulosa cells. Endocrinology 114, 441-449.

Wang, J. \& Leung, P.C. (1987) Role of protein kinase C in luteinizing hormone-releasing hormone (LHRH)stimulated progesterone production in rat granulosa cells. Biochem. Biophys. Res. Commun. 146, 939-944.

Zeleznik, A.J. (1979) Regulation of pregnenolone metabolism in developing granulosa cells by follicle stimulating hormone. Biol. Reprod. 20 (Suppl. 1), 49A, Abstr.

Received 3 October 1988 